\section{The Starfish}

THE eighth number of The Starfish, the journal of the Association of School Natural History Societies, is, like its predecessors, a tribute to the vitality and enthusiasm of natural history students and their teachers in British grammar schools. Mr. A. R. P. Hayden contributes the main article, which describes the work of the Nature Conservancy; David Spires, of Bishop's Stortford College, writes on observations he has made on the ecology of the house-sparrow during 1953-54; and R. J. Cryer, of St. Paul's School, gives an account of his investigation into a shaker mutant in mice. The usual reports from member schools are included, as are the yearly observations on mammals, birds, butterflies and moths, and plants. The report on the annual essay competition describes the number of entries as being particularly disappointing. A charge of $2 s$. for the journal is made to non-members of the Association. Each year the Socicty holds an exhibition which, in 1955, will be held in London at the British Museum (Natural History) on October 15; it is open to the public.

\section{Fat Accumulation by Algae}

ON the basis of extensive analyses, D. M. Collyer and G. E. Fogg have come to the conclusion that the generally held view that fat accumulation is characteristic of certain classes of algae stands in need of revision ( $J$. Exp. Bot., 6, 17, 256; 1955). In the investigations now reported, the fatty acid, unsaponifiable lipoid, total cell nitrogen and polysaccharide contents of representative algae from different classes have been ascertained at different stages during their growth in pure culture. Species belonging to the same class have been found to resemble each other in the relative amounts of crude protein, fats and hydrolysable polysaccharide which they contain. Marked differences in composition between species belonging to different classes have been found; but it is concluded that there are no fundamental differences in the physiological relations of fat accumulation in the algae belonging to the Chlorophyceae, Euglenineae, Xanthophyceae and Bacillariophyceae. Representatives of the Rhodophyceae and Myxophyceae, although they may in certain circumstances have moderately high fat contents, appear to differ in that in them fat accumulation is not associated with low cell nitrogen contents as it is in the other algae examined. No well-defined correlations between the unsaponifiable lipoid and either the fatty acid or total cell nitrogen contents of the algae have been found. Euglena gracilis var. bacillaris has been found to have a rather higher content of unsaponifiable lipoid than the other algae.

\section{Zoological Nomenclature}

As from January 7, 1956, the International Commission on Zoological Nomenclature will start to vote on the following cases involving the possible use of its plenary powers for the purposes specified against each entry. Full particulars of these cases have already been published (Bull. Zool. Nom., 11, Parts 7 and 8 ; 1955). (1) Gnathophyllum Latreille, 1814 (Cl. Crustacea, Order Decapoda), validation of emendation from Gnatophyllum ; Hippolytidae Bate, 1888, and Eugonatonotidae Chace, 1937, validation of ; (2) Mayaitidae Spath (L.F.), 1928 (Cl. Cephalopoda, Order Ammonoidea), validation of; (3)
Lernaeocera Blainville, 1822 (Cl. Crustacea, Order Copepoda), validation of emendation from Lerneocera, and designation of a type species for; (4) proposed grant to the International Commission of authority to prescribe for generic names a gender different from that grammatically appropriate where such action is needed in the interests of nomenclatorial stability ; (5) determination of a gender for (a) generic names in the Class Aves having the termination -rhynchus; (b) generic names in the Order Decapoda (Cl. Crustacea) having the terminations -opsis and -gnathus; (c) for the following names -Gigantorhynchus Hamann, 1892 (Cl. Acanthocephala); Desmognathus Baird, 1850 (Cl. Amphibia); Nephrops Leach, [1814] (Cl. Crustacea, Order Decapoda); Syngnathus Linnaeus, 1758 (Cl. P'isces) ; (6) Varuna Milne Edwards, 1830 (Cl. Crustacea, Order Decapoda), validation of currently accepted gender for. Proposals are also made for the adoption of the following Declarations : (a) Article 21: clarification of the authorship to be attributed in certain circumstances to zoological names and to actions affecting the status of such names ; (b) Article 25: clarification of the status of names published only in the indexes of books. Comments should be sent as soon as possible to the secretary to the Commission, Mr. Francis Hemming, 28 Park Village East, Regent's Park, London, N.W.1.

\section{Announcements}

THE fourth Coal Science Lecture of the British Coal Utilization Research Association is to be delivered by Sir Cyril Hinshelwood on October 19 at 5.30 p.m. in the lecture theatre of the Institution of Civil Engineers. He will speak on "The Carbon of Coal". Tickets are available from the Secretary of the Association (B.C.U.R.A., Randalls Road, Leatherhead, Surrey).

THE Bedson Club, King's College, Newcastle upon Tyne, will be holding its hundredth lecture on October 26, when Prof. M. Calvin (University of California, Berkeley) will speak on "The Photosynthetic Carbon Cycle". Two further lectures will be given as follows: November 25, Prof. E. A. Guggenheim (University of Reading), "The Relation between Theory and Experiment in. Physical Chemistry"; and January 27, Dr. F. Sanger (King's College, Cambridge), "The Chemistry of Insulin".

THE Council of the International Union of Pure and Applied Chemistry has approved the recommendation of the Union's Commission on Nomenclature in Inorganic Chemistry that element 101 be named Mendelevium, symbol Mv. The original recommendation for this move was made at the eighteenth conference of the Union at Zurich during July 20-28, and was based on the claims of A. Ghiorso, B. G. Harvey, G. R. Choppin, S. G. Thompson and G. T. Seaborg, of the University of California, as announced in a report printed for the United States Atomic Energy Commission, UCRL-2943 (contract No. W-7405-eng-48), "The New Element Mendelevium", dated April 4, 1955.

ERratum. In Nature of August 27, p. 379, in the paragraph on super-voltage machines for X-ray therapy in the Science Museum, the misleading impression is given that betatrons and synchrotrons are widely used for hospital radiotherapy in Great Britain. They are, in fact, used for research purposes; for radiotherapy the travelling-wave linear electron-accelerator is being installed in a number of hospitals. 